\title{
The extraction of glycogen from marine invertebrate tissues
}

\author{
Harold Barnes and John R. Heath \\ The Marine Station, Millport, Scotland \\ and \\ The Biology Department, University of Stratbclyde, Scotland
}

\begin{abstract}
KURZFASSUNG: Die Glykogenextraktion aus dem Gewebe mariner Invertebraten. Es wird der Nachweis geführt, daß die Glykogenextraktion aus den Geweben einiger mariner Invertebraten (Balanus balanoides, Nepbtys bombergi, Carcinus maenas, Mytilus edulis) durch $5 \%$ Trichloressigsäure von dem Homogenisierungsverfahren abhängt. In Übereinstimmung mit Untersuchungen an Rattengewebe können die Glykogenfraktionen nicht durch ihre Löslichkeit in kalter $5 \%$ Trichloressigsäure unterschieden werden. Daher ist nur die Bestimmung des Gem samt-Glykogengehaltes angebracht.
\end{abstract}

\section{INTRODUCTION}

It has long been customary to separate the glycogen of animal tissues into that fraction soluble in cold $5 \%$ trichloraceric acid and that insoluble in this reagent. These fractions have been variously designated as free-bound, lyo- and desmo-, trichloracetic extractable - residual glycogen, and different metabolic roles have often been suggested for them (see STETTEN \& STETTEN 1960, for a review). Recently, however, Roe et al. (1961) have shown that, if an adequate homogenization procedure is used, all the glycogen in rat tissues can be extracted with cold $5 \%$ trichloracetic acid. It is important to know whether the conclusions of RoE et al. are applicable when dealing with marine invertebrate tissues in which two "forms" of glycogen have often been separated by their "solubility" in $5 \%$ trichloracetic acid and have frequently been assigned different metabolic functions. In order to obtain complete extraction RoE et al. used a Vir Tis homogenizer running at $45.000 \mathrm{rev} . / \mathrm{min}$. for 5 minutes with the addition of glass beads.

\section{MATERIAL AND METHODS}

Whole bodies, separated from the shells, of Balanus balanoides, the sot parts of Mytilus edulis, whole Nephtys hombergi, and the hepatopancreas of Carcinus maenas were used as representative of invertebrate tissues known to contain quantities of glycogen. 
The material was chopped up when necessary (Mytilus, Nephtys) and, after removing the excess water by thorough blotting with filter paper, was then dried as rapidly as possible under continuous vacuum in a desiccator; material prepared in this way is frequently used in biochemical-ecological studies. When dry, the solid was broken up and powdered in a pestle and mortar. It was found difficult to reduce the Mytilus and Nepbtys material to a homogeneous powder and in preliminary experiments the results were inconsistent; the fraction passing a fine sieve was therefore used. A Vir Tis homogenizer was not available; a Bühler homogenizer with arbitrary speed settings was used.

KeMp \& Kits yan HeIjningen (1954) have shown that the total carbohydrate (glycogen plus "glucose") in tissues can be extracted with hot $5 \%$ trichloracetic acid and then estimated by a colour reaction with sulphuric acid. The total carbohydrate and glucose in each sample of material were first determined by this method. A weighed quantity (50-200 $\mathrm{mg}$ depending upon the carbohydrate content) was homogenized with $5 \%$ trichloracetic acid with the addition of $50 \mathrm{mg}$ solid silver sulphate (to remove chloride) in a Potter-Elvehjem homogenizer. The homogenate was heated for 15 minutes in a boiling water bath to extract all the glycogen plus hexoses. After centrifuging, the supernatant, to which was added the washings of the residue with $5 \%$ trichloracetic acid, was filtered through a Whatman 42 paper and made up to a known volume (the solution may contain up to $1.5 \mathrm{mg}$ carbohydrate $/ \mathrm{ml}$ ). One $\mathrm{ml}$ of this clear solution was then added to $3 \mathrm{ml}$ of concentrated sulphuric acid and the mixture immediately shaken vigorously. After heating for exactly 6.5 minutes in a boiling water bath and then cooling, the absorbancy was measured at $520 \mathrm{~m} \mu$. Replicate estimations were made; a calibration curve was set up using pure glucose. The glycogen alone was then determined by digesting a weighed quantity of tissue with sodium hydroxide and precipitating with ethanol taking the precautions indicated by VAN HANDEL (1965). The precipitate was taken up in $5 \%$ trichloracetic acid, heated for 15 minutes at $100^{\circ} \mathrm{C}$, centrifuged when necessary, and glycogen estimated as above in the supernatant. Glu-

Table 1

Glycogen recovered from tissues expressed as a percentage of that obtained by hot TCA extraction: Bühler homogenizer at constant speed: details of preparation of the material in text

\begin{tabular}{|ccccc|}
\hline $\begin{array}{c}\text { Homogenization } \\
\text { (minutes) }\end{array}$ & Balanus balanoides & Mytilus edulis & Nephtys bombergi & Carcinus maenas \\
\hline 1 & 7 & 97 & 15 & 65 \\
2 & 33 & 92 & 34 & 73 \\
6 & 59 & 99 & 45 & 96 \\
12 & 100 & 102 & 69 & 96 \\
\hline
\end{tabular}

cose is given by the difference from total carbohydrate. All subsequent total carbohydrate values were corrected for this glucose, which is readily extracted with cold trichloracetic acid.

Weighed quantities of the materials under investigation were then homogenized (at a fixed speed rating) in the Buhler with $5 \%$ cold trichloracetic acid and solid silver sulphate for increasing periods of time. In each case, the homogenate was centrifuged, 
the residue washed, and the supernatant after filtration made up to volume. The carbohydrate was then determined directly - without any heating - on $1 \mathrm{ml}$ of this solution.

\section{RESULTS AND DISCUSSION}

The results are shown in Table 1 which gives the recovery of glycogen, expressed as a percentage of that extracted by the hot trichloracetic acid procedure for each material at a series of homogenization times at constant speed.

It is clear that the amount of glycogen obtained increases with increasing time of homogenization and that it soon approaches the total glycogen content as estimated by extraction with hot trichloracetic acid. If a Vir Tis homogenizer running at full speed with the addition of glass beads had been available, there seems little doubt that complete extraction would have been obtained under the conditions used by RoE et al. For the present purpose, however, it is sufficient to appreciate that the amount of glycogen extracted is a function of the homogenization, that no clear fractionation with respect to cold trichloracetic acid is indicated, and that the value soon approaches that given by hot trichloracetic acid extraction.

In marine invertebrate tissues, as RoE et al. have indicated for rat tissues, there seems little point in distinguishing the glycogen extracted by cold trichloracetic acid from the remainder. Only the total glycogen need be estimated and this may be done by the method indicated above or by any of the classical precipitation techniques with the precautions indicated by VAN HANDEL (1965) after alkali digestion. It should perhaps be emphasized that this statement does not imply that different forms of glycogen may not exist - they almost certainly do - but only that they are not normally differentiated by their solubility in cold trichloracetic acid.

\section{SUMMARY}

1. It is shown that the extraction by $5 \%$ trichloracetic acid of glycogen from the tissues of some typical marine invertebrates (Balanus balanoides, Nephtys hombergi, Carcinus maenas, Mytilus edulis) is a function of the homogenization procedure.

2. In agreement with work on rat tissues, glycogen fractions cannot be differentiated by their solubility in cold $5 \%$ trichloracetic acid. Total glycogen only need be determined.

\section{LITERATURE CITED}

Handed, E. van, 1965. Estimation of glycogen in small amounts of tissue. Analyt. Biochem.11, 256-265.

Kemp, A. \& Kits van Herjningen, A. J. M., 1954. A colorimetric micro-method for the determination of glycogen in tissues. Biochem. J. 56, 646-648.

Roe, J. H., Bartey, J. M., Gray, R. R. \& Robinson, J. N., 1961. Complete removal of glycogen from tissues by extraction with cold trichloracetic acid solution. J. biol. Chem. 236, $1244-1246$.

Stetten, D. (Jr.) D. \& Stetten, M. R., 1960. Glycogen metabolism. Physiol. Rev. 40, 505-537. 